\title{
New distribution record of the weakly electric fish Steatogenys ocellatus Crampton, Thorsen \& Albert 2004, in the Putumayo River, upper Amazon river basin, Colombia
}

\author{
Juan D. Bogotá-Gregory, ${ }^{1,2}$ César A. Bonilla-Castillo, ${ }^{1}$ Edwin Agudelo Córdoba ${ }^{1}$ \\ 1 Instituto Amazónico de Investigaciones Científicas SINCHI, Avenida Vásquez Cobo entre Calles 15 y 16, Leticia, Amazonas, Colombia. 2 \\ University of Central Florida, Department of Biology, 4000 Central Florida Boulevard, Orlando, FL, USA 32816 \\ Corresponding author: Juan D. Bogotá-Gregory, juandbogota@gmail.com
}

\begin{abstract}
The natural distribution of Steatogenys ocellatus Crampton, Thorsen \& Albert 2004, is expanded here with a specimen collected near Puerto Leguízamo (Colombia) in the Río Putumayo at the Colombian-Peruvian border. This record, the first for this species in Colombia, expands its geographical distribution within the Amazon basin to a new watershed. Furthermore, this is the first time $S$. ocellatus has been recorded in a white water system.
\end{abstract}

\section{Key words}

Amazonian knifefish; Rhamphichthyidae; Neotropic.

Academic editor: Henrique Lazzarotto | Received 28 February 2017 | Accepted 26 June 2018 | Published 27 July 2018

Citation: Bogotá-Gregory JD, Bonilla-Castillo CA, Agudelo Córdoba E (2018) New distribution record of the weakly electric fish Steatogenys ocellatus Crampton, Thorsen \& Albert 2004, in the Putumayo River, upper Amazon river basin, Colombia. Check List 14 (4): 609-612. https://doi. org $/ 10.15560 / 14.4 .609$

\section{Introduction}

The Neotropical electric fishes, also called American knifefishes (Gymnotiformes), are a diverse group with 240 designated species and possess a specialized morphology (Ferraris et al. 2017), characterized by their elongated body plan and the absence of dorsal and pelvic fins (in most families the caudal fin is also absent). The most remarkable feature of the group is the presence of an electric organ with the ability to generate an electric field, mostly a weak one, except in the well-known monotypic genus Electrophorus Gill 1864, which is able to generate a discharge that could reach 600 volts (Gotter et al. 1998). This electric field is detected by an array of electroreceptors distributed across their body (Lissmann 1958). This combined system is used to communicate and to locate objects (Carr and Maler 1986). Until recently, the genus Steatogenys Boulenger 1898 was included within the family Hypopomidae, but currently it is part of the Rhamphichthyidae, which comprises 5 genera and 27 species (Ferraris et al. 2017), that generally are laterally compressed, moderate-to-large sized gymnotiforms, and lack a caudal fin, as seen in the Apteronotidae family. The genus Steatogenys comprises 3 species, making it a small group within the Gymnotiformes (Albert 2001, Crampton et al. 2004, Albert and Crampton 2005). Its short snout, rounded head, subterminal mouth, and pigmentation pattern may distinguish Steatogenys species from other genera. To describe Steatogenys ocellatus Crampton, Thorsen \& Albert 2004, the authors used a variety of features from specimens collected in the lowland Amazon basin near Tefé and Iquitos in Brazil and 


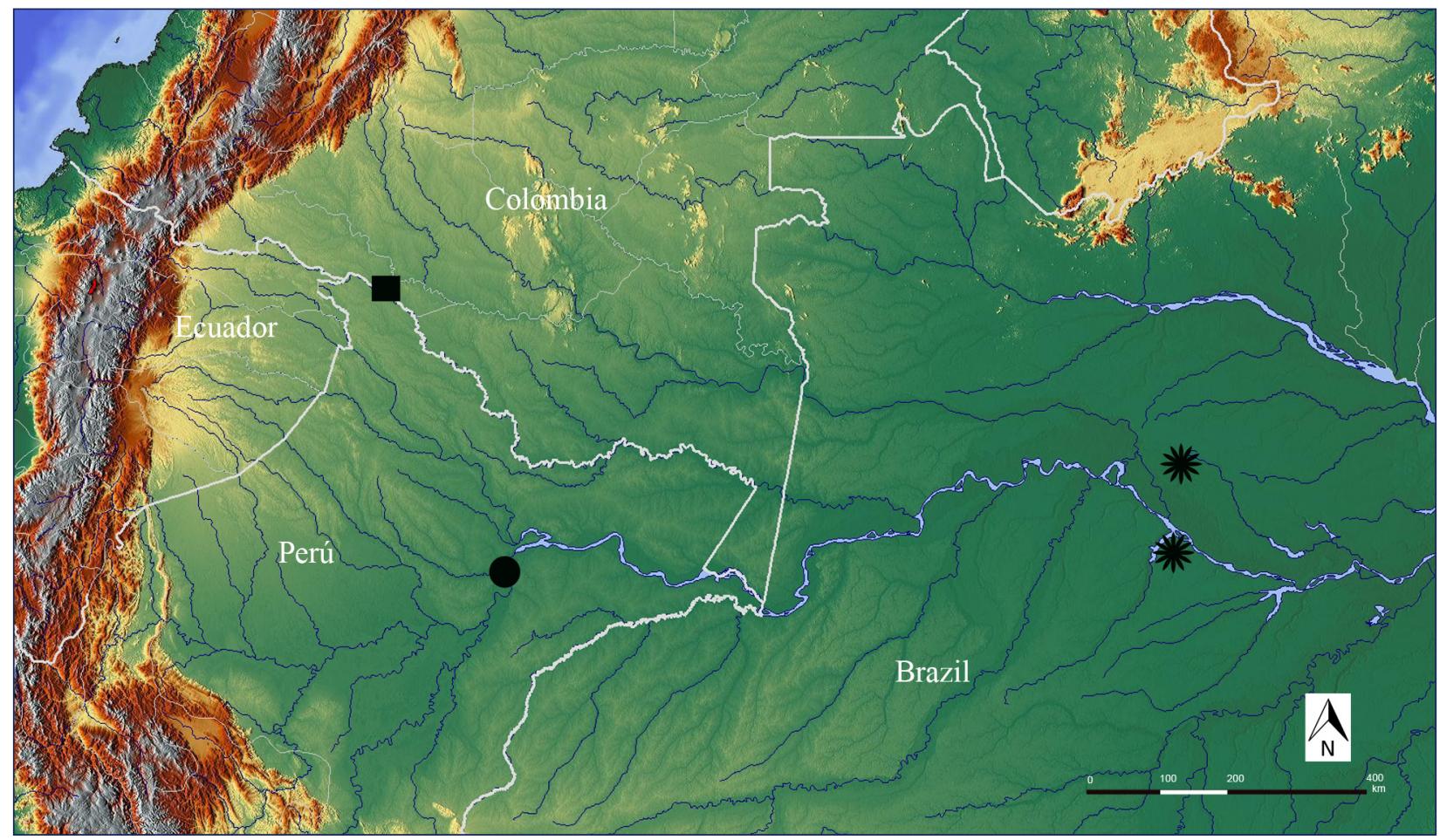

Figure 1. Distribution area of Steatogenys ocellatus. (a) Stars represent type localities at Lago Amanã and Lago Tefé (Brazil); (b) Circle represents Río Itaya (Perú); (c) Square represents the new record at Puerto Leguizamo, Colombia on the Colombian-Peruvian border.

Perú, respectively (Fig. 1). A large body size, oval spot on the pectoral fin base and an irregular pattern of dark pigmentation on the pectoral fin are the characteristics used to identify species within the genus Steatogenys (Fig. 2).

Among its congeners, $S$. ocellatus is the only species restricted to the Amazon basin, while the other 2 species, S. elegans (Steindachner 1880) and S. duidae (La Monte 1929) are recorded in both the Amazon and Orinoco basins. This is a pattern for most of the gymnotiforms, as they are distributed in 2 or more hydrogeographic regions (Albert and Crampton 2005).

The type locality for $S$. ocellatus is a typical black water system at Lago Amanã and Lago Tefé in Brazil. However, specimens collected in the Manzana Creek, affluent of the Río Itaya in Perú (Ferraris et al. 2017), were also identified as S. ocellatus (Fig. 1). The natural distribution of $S$. ocellatus is increased here with a single specimen collected near Puerto Leguizamo (Colombia) in the Río Putumayo basin at the Colombian-Peruvian border (Fig. 1).

\section{Methods}

The specimen was collected with conventional gill-nets (60 $\mathrm{mm}$ eye mesh), setup parallel to the shore during the night, along the deep banks ( $>4 \mathrm{~m}$ depth) of the of the main channel of the Putumayo River, near Puerto Leguizamo. These river banks are typically formed by exposed sediments stabilized by riparian vegetation and are flooded for up to half of the hydrological annual cycle (during high-water season, the highest water levels are registered between May and July (IGAC, 1999)). Despite changes in the water systems due to seasonal flooding, changes in the river caudal are not significant in relation to flooding cycle (IGAC, 1999), and average width of the river channel at the collection location is approximately $500 \mathrm{~m}$. The Putumayo River corresponds to a system of pre-Andean origin, which is one of the biggest affluent of the Amazon basin in the Colombian territory. Once the Putumayo River reaches the Brazilian territory it changes name to Rio Içá. Due to its origin, the main river channel carries heavy loads of suspended sediment, as well as relatively high loads of dissolved salts (Welcomme 1979, Junk 1985, Mertes 1985). The Putumayo River represents a typical white water system of Andean and pre-Andean origin (IGAC, 1999): $\mathrm{pH}$ close to neutral (6-7), high conductivity (between 50 and $300 \mu \mathrm{S} / \mathrm{cm}$ ), and high turbidity $(>10$ NTU).

New Record. Colombia: Putumayo Department: Main channel of the Putumayo River, near Puerto Leguizamo (ca $00^{\circ} 12^{\prime} 28^{\prime \prime} \mathrm{S}, 074^{\circ} 46^{\prime} 52^{\prime \prime} \mathrm{W}$, elevation at Puerto Leguizamo is $115 \mathrm{~m}$ above sea level), collected by Gómez Hurtado and Bonilla Castillo, under the framework of the project "Investigación Científica para la Gestión Compartida, 1 May 2009 and deposited in the Colección Ictiológica de la Amazonia Colombiana (CIA$\mathrm{COL}$ ) of the SINCHI Institute, with the catalog number CIACOL-513.

Identification. The specimen was first erroneously identified as Sternarchogiton cf. nattereri, but a systematic revision done in 2012 allowed us to identify it properly. To compare with the type material, protocol for specimen identification followed the same meristic and count 


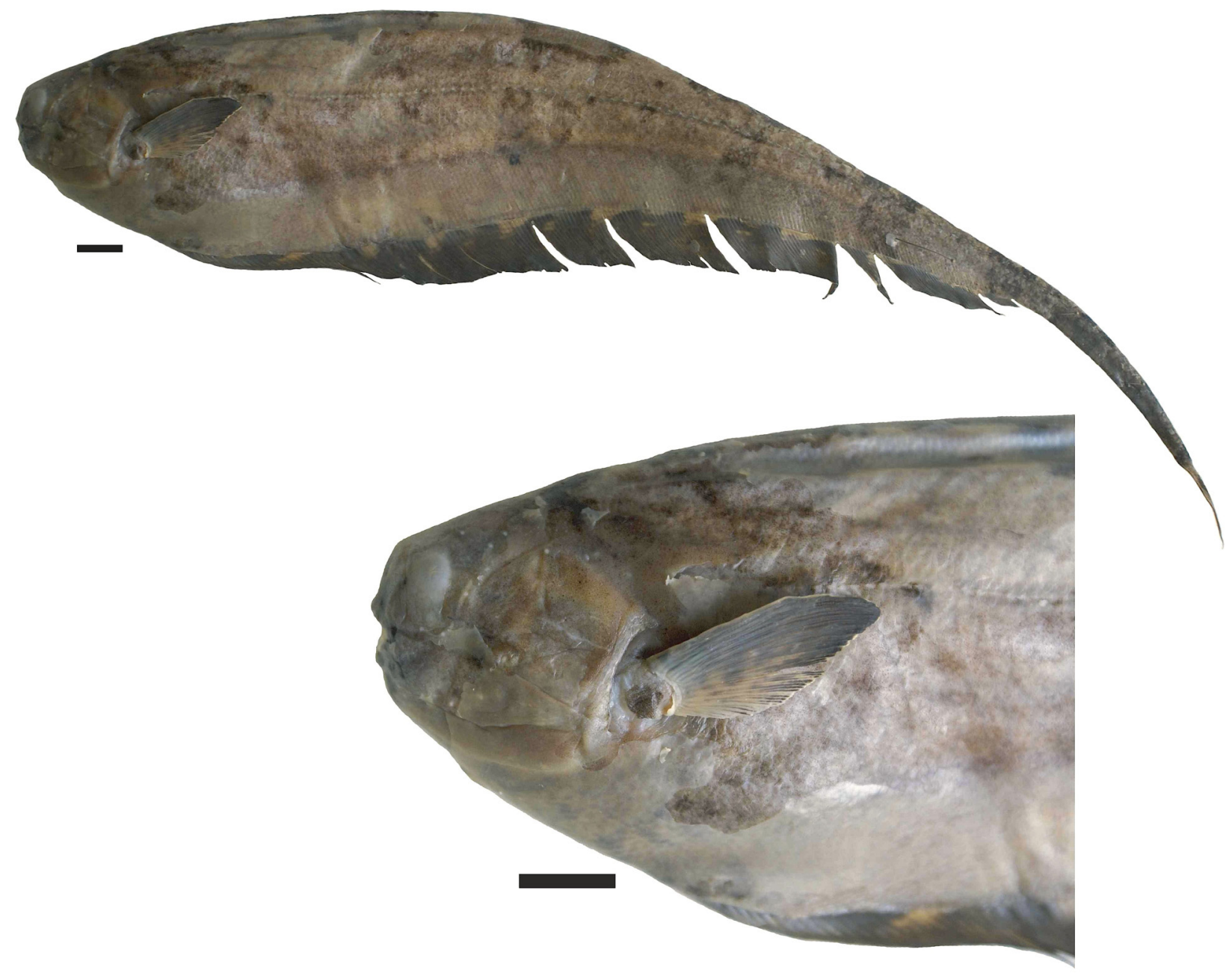

Figures 2. Steatogenys ocellatus, CIACOL 513. Scale bars $=10 \mathrm{~mm}$.

methods as Crampton et al. (2004). The specimen is $330.02 \mathrm{~mm}$ in total length; contains a conspicuous dark spot at the base of pectoral-fin base, an irregular pattern of pectoral-fin pigmentation, 13 pectoral-fin rays (fewer than type specimens), 182 anal-fin rays, 10 scales over lateral line, and 103 lateral line scales. With the exception of the pectoral-fin rays, meristic counts are within the ranges of the type specimens. Most of the morphometric measurements fall within the ranges of those from type specimens (Table 1). Nevertheless, body depth and body width, measured as percentage of the length to the end of the anal fin (LEA), differ significantly. We assume that there must be a mistake in the original description manuscript for these 2 measurements, because it is highly improbable that the body depth values are greater than the LEA.

\section{Discussion}

Type locality of $S$. ocellatus is a typical black-water system that is characterized by low conductivity and $\mathrm{pH}$, and its color is due to the low sediment concentration and the high level of humic and fulvic acids derived from the degradation of soil vegetation (Sioli 1984). Our findings not only confirm its distribution in the Putumayo River in Colombia, but also confirms that this species

Table 1. Morphometric data comparisons. For abbreviations, see Crampton et al. (2004: table 1).

\begin{tabular}{lcc}
\hline $\begin{array}{l}\text { Morphometrics } \\
(\mathbf{m m})\end{array}$ & $\begin{array}{c}\text { Specimen C } \\
\text { IACOL }\end{array}$ & $\begin{array}{c}\text { Ranges } \\
\text { Crampton et al. 2004 }\end{array}$ \\
\hline TL & 330 & $132-405$ \\
LEA & 242.6 & $97-320$ \\
LEA \%** & 73.5 & $70.4-83.8$ \\
HL\%* & 10.7 & $10.7-13.5$ \\
PR\% & 28.8 & $29.0-35.5$ \\
PO\% & 67.8 & $64.2-69.7$ \\
SO\% & 84.8 & $85.5-92.5$ \\
HD\% & 136.7 & $99.7-108.4$ \\
HW\% & 88.8 & $57.4-80.4$ \\
PA\% & 103 & $73.7-92.3$ \\
P1\% & 114.9 & $68.2-90.5$ \\
AF\%** & 73 & $60.4-72.1$ \\
BD\%* & 20.7 & $135.7-186.8$ \\
BW\%* & 9 & $45.2-68.5$ \\
CA\%** & 25.9 & $11.4-29.6$ \\
CD\% & 29.6 & $16.2-27.8$ \\
\hline
\end{tabular}


inhabits white water systems of Andean origin, where environmental parameters differ from those of black water systems.

Differences in morphometric measurements showed between the specimen referenced here and the specimens collected previously - including type specimens - might correspond to a geographical variation. The same variation in morphometric measurements was denoted between specimens from the localities reported previously (see morphometric measurements in Crampton et al. (2004)). Future studies might provide more insights into the true sources of morphological variation and identify the effect of the environmental conditions on population divergences. Even though these congeners comprise very few species, they are highly adapted to different circumstances regarding water chemistry and hydromorphological characteristics of the habitat. As evidenced here with the specimen collected in the Rio Putumayo, and as mentioned by Crampton (2011), representatives of the genus are among the few exceptions of pulse-type species that are found in deep-channel rivers. Furthermore, there is evidence of structural differences of the electric organ due to conductivity of the water (Albert and Crampton 2005). To improve our knowledge of the degree to which water quality influences such morphological differences, new studies can be proposed including $S$. ocellatus to aid in understanding the keystones of evolution of one of the most important components of the most diverse ichthyofauna in the world.

This new record expands the ecological and geographical distribution of the species within the Amazon basin and is the first appearance of this species from Colombia in the upper Amazon, where S. ocellatus was yet to be found. However, it could be expected from our findings, that its natural distribution range would be over a wider area because it could inhabit unexplored areas of the Amazon basin, especially in Colombia.

\section{Acknowledgements}

Astrid Acosta for support during the taxonomic revision of the CIACOL of the SINCHI Institute. This paper is part of the program "Investigación en Ecosistemas y Recursos Naturales de la Amazonia Colombiana 20092012", funded by the SINCHI Institute. Joe Waddell and Lauren Caspers for comments and English revision.

\section{Author contributions}

JDBG identified the specimen, wrote the text and made the analysis; $\mathrm{CB}$ and $\mathrm{EAC}$ in the analysis and collection of the specimen.

\section{References}

Albert JS (2001) Species diversity and phylogenetic systematics of American knifefishes (Gymnotiformes, Teleostei). Miscellaneous Publications Museum of Zoology, University of Michigan 190: 11-27.

Albert JS, Crampton WGR (2005) Diversity and phylogeny of Neotropical electric fishes (Gymnotiformes). In: Bullock TH, Hopkins CD, Popper AN, Fay RR (Eds) Electroreception. Springer Handbook of Auditory Research, New York, 360-409.

Carr CE, Maler L (1986) Electroreception in gymnotiform fish: central anatomy and physiology. In: Bullock TH, Hellingenberg W (Eds) Electroreception. Wiley-Interscience, New York, 319-374.

Crampton WGR (2011) An ecological perspective on diversity and distributions. In: Albert JS, Reis RE (Eds) Historical Biogeography of Neotropical Freshwater Fishes. University of California Press, Berkeley, 165-189.

Crampton WGR, Thorsen DH, Albert JS (2004) Steatogenys ocellatus: A new species of Neotropical electric fish (Gymnotiformes: Hypopomidae) from the lowland Amazon basin. Copeia 2004 (1): 78-91. http://doi.org/10.1643/ci-03-072ri

Ferraris CJ, Santana CD de, Vari RP (2017) Checklist of Gymnotiformes (Osteichthyes:Ostariophysi) and catalogue of primary types. Neotropical Ichthyology 15 (1): e160067. http://doi.org/10.1590/19820224-20160067

Gotter AL, Kaetzel MA, Dedman JR (1998) Electrophorus electricus as a model system for the study of membrane excitability. Comparative Biochemistry and Physiology Part A: Molecular \& Integrative Physiology 119 (1): 225-241. https://doi.org/10.1016/ s1095-6433(97)00414-5

Junk WJ (1985) The Amazon floodplain — a sink of source for organic carbon? Mitteilungen aus dem Geologisch-Paläontelogischen Institute der Universität Sonderband, Hamburg 58: 267- 283.

Lissmann HW (1958) On the function and evolution of electric organs in fish. The Journal of Experimental Biology 1301 (35): 156-191.

Mertes LAK (1985) Floodplain Development and Sediment Transport in the Solimões-Amazon River, Brazil. M.Sc. dissertation, University of Washington, $108 \mathrm{pp}$.

Sioli H (1984) The Amazon and its main affluents: Hydrography, morphology of the river courses, and river types. In: Sioli S (Ed) The Amazon: Limnology and Landscape Ecology of a Mighty Tropical River and its Basin. Dr. W. Junk Publishers, Dordrecht, 127-165.

Welcomme RL (1979) Fisheries Ecology of Floodplain Rivers. Longman, London, $317 \mathrm{pp}$. 